
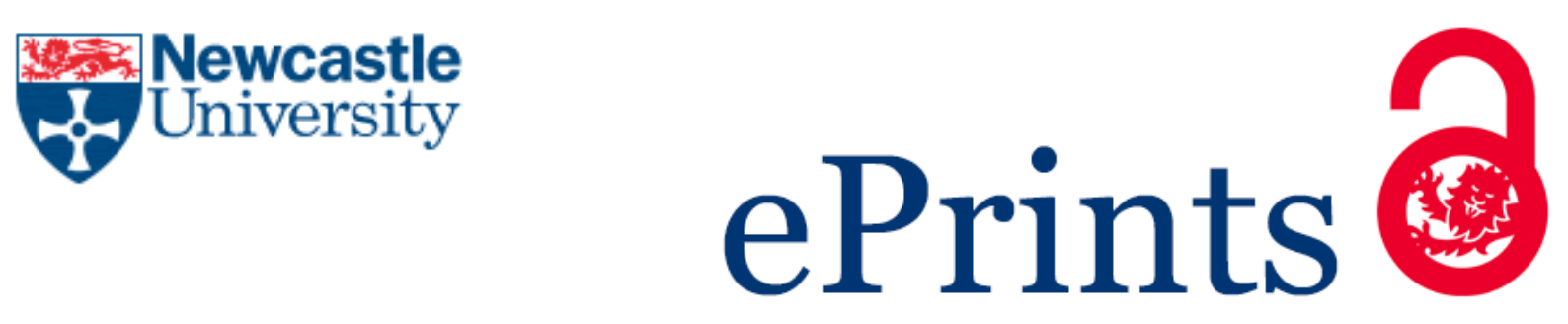

Farrand B. (2019)

Digital Copyright and Human Rights: A Balancing of Competing Obligations, or Is There No Conflict?.

In: Wagner, B; Kettemann, C; Vieth, K, ed. Research Handbook on Human

Rights and Digital Technology: Global Politics, Law and International Relations. Cheltenham: Edward Elgar, pp.53-72.

\title{
Copyright:
}

This is a draft chapter. The final version is available in Research Handbook on Human Rights and Digital Technology: Global Politics, Law and International Relations edited by B. wagner, C. Kettemann and K. Veith, published in 2019, Edward Elgar Publishing Ltd. http://dx.doi.org/10.4337/9781785367724.00010

The material cannot be used for any other purpose without further permission of the publisher, and is for private use only.

Date deposited:

$07 / 04 / 2019$

Embargo release date:

25 July 2019 


\section{Digital Copyright and Human Rights: - A Balancing of Competing Obligations, or Is There No Conflict?*}

Copyright protection on the Internet has become an inherently political and contested subject. With increased access to Internet, has come a dramatic, and indeed exponential increase in both the desire to create, as well as access information. However, in the sharing of information, it is also possible that Internet users may infringe copyright. Actions seeking to restrict, prevent or seek redress for copyright infringement may in turn have implications for other rights, such as privacy or freedom of expression. This is a fact that has been recognised by international bodies; stating that 'there are apparent conflicts between the intellectual property rights regime [...] and international human rights law', ${ }^{1}$ the UN SubCommission on Human Rights indicated that these conflicts were likely to exacerbate informational, social and economic inequalities at the international level. Yet whether there is a conflict between copyright and other fundamental rights, or indeed whether copyright protection should be afforded human right status are subjects of debate. One key distinction is that between the EU, and its focus on human and fundamental rights, and the US, in which fundamental rights are not recognised as such, but may instead be considered as rights originating in the US Constitution. On this basis, this paper seeks to answer the question 'what tensions exist between copyright protection on the Internet and other categories of human right?' The chapter explores this further by providing an overview of what copyright protects, arguments concerning its human rights status at international, regional and national levels, as well as whether copyright protection is perceived to conflict with other rights. As this chapter will demonstrate, whereas the EU recognises copyright protection as a human or fundamental right, drawing from international conventions on human rights protection, the US does not afford those international conventions the same legal weight; furthermore, due to historical differences, the notion of 'human rights' is not as present in US-based legal discourse. References are instead to Constitutional rights. In the EU, European Court of Justice (CJEU) jurisprudence has concluded that copyright as a fundamental right can come into conflict with other competing fundamental rights obligations such as the right to privacy, or freedom of expression. For this reason, a balance

\footnotetext{
* Dr Benjamin Farrand, Assistant Professor, University of Warwick

1 Sub-Commission on Human Rights Resolution 2000/7 on Intellectual Property Rights and Human Rights, Office of the High Commissioner for Human Rights, para. 2
} 
must be struck. In comparison, jurisprudence in the US considers that copyright facilitates expression, as was the Constitutional intent, therefore meaning that consideration of limits on freedom of speech resulting from copyright protection are not subject to Constitutional analysis, as there is no perceived conflict. Regardless of these jurisprudential differences, however, citizens in the EU and US both see strong copyright protection on the Internet as having significant implications for both privacy and freedom of expression; rather than copyright and human rights as being a field of 'no conflict', it instead represents an uneasy tension in which a balance must continually be (re)struck.

\section{COPYRIGHT AS A HUMAN RIGHT: - FROM GLOBAL PRINCIPLES TO EU JURISPRUDENCE}

Copyright, briefly, concerns the protection of creative works, defined as 'literary and artistic works [...including] every production in the literary, scientific and artistic domain' under the Berne Convention, ${ }^{2}$ the international agreement serving as the basis for the international protection of copyright under the Trade Related Aspects of Intellectual Property Rights Agreement (the TRIPS Agreement, hereafter TRIPS). Concluded in 1994 and entering into force in 1995, Article 9 of TRIPS requires that all States party to the World Trade Organization shall incorporate Articles 1 to 21 of the Berne Convention into their national laws. ${ }^{3}$ Copyright protection therefore extends to all forms of creative content made available in digital forms on the Internet, whether sound recordings in the form of MP3s, audiovisual works encoded as AVI or Flash files, eBooks, or computer programmes. Copyright grants the right-holder exclusive rights over acts such as the reproduction of a work, or its communication or distribution to the public, ${ }^{4}$ meaning that by performing these acts without the authorisation of the right-holder, an end-user of a computer system may infringe copyright.

One may be forgiven, then, for thinking that copyright is solely a creature of private law relationships, and commercial activity. The TRIPS Agreement can be considered an economic treaty, concerned with intellectual property insofar as it relates to the protection

\footnotetext{
${ }^{2}$ Berne Convention for the Protection of Literary and Artistic Works 1886, Article 2(1)

${ }^{3}$ With the exception of Article 6bis of the Berne Convention, which pertains to the protection of an author's moral rights.

${ }^{4}$ Incorporated into EU law under Articles 2, 3 and 4 of Directive 2001/29/EC on the harmonisation of certain aspects of copyright and related rights in the information society
} 
of property in the context of international trade, and as such, no reference to intellectual property and human rights is made. Indeed, studies of intellectual property law, particularly those associated with the law and economics movement, appear to reinforce such a perception. ${ }^{5}$ Furthermore, those authors seeking to provide greater justification for intellectual property protection, whether using 'rights-based' discourse ${ }^{6}$ or appeals to maximising the utility of creative works, ${ }^{7}$ or instead critiquing the assumptions upon which such justifications are traditionally based, ${ }^{8}$ tend toward the grounding of arguments in economic analysis. ${ }^{9}$ However, another way of reconceptualising the protection of copyright, and indeed the tensions that such protection creates, can be in terms of human rights. Such an approach to intellectual property protection is not new, and has in recent years generated considerable academic interest. ${ }^{10}$ The consideration of the right to protection of copyright can be traced back to the genesis of human rights as universal principles. Article 27(1) of the Universal Declaration of Human Rights of 1948 states that everyone is free to participate in the cultural and scientific life of the community, with Article 27(2) declaring that furthermore, everyone 'has the right to the protection of the moral and material interests resulting from any scientific, literary or artistic production of which he is the author'. In other words, copyright protection is regarded as a category of right recognised as representing the 'inherent dignity [and] the equal and inalienable rights of all members of the human family'.11 While the consideration of intellectual property rights was subject to

\footnotetext{
${ }^{5}$ See in particular Richard A Posner, 'Intellectual Property: The Law and Economics Approach' (2005) 19 Journal of Economic Perspectives 57; see also Niva Elkin-Koren and Eli M Salzberger, The Law and Economics of Intellectual Property in the Digital Age: The Limits of Analysis (Routledge 2013); Michele Boldrin and David K Levine, Against Intellectual Monopoly (Cambridge University Press 2008) for alternative economic views on copyright law.

${ }^{6}$ Robert P Merges, Justifying Intellectual Property (Harvard University Press 2011).

${ }^{7}$ As discussed in Anne Barron, 'Copyright Infringement, "free-Riding" and the Lifeworld' in Lionel Bently, Jennifer Davis and Jane C Ginsburg (eds), Copyright and Piracy: An interdisciplinary critique (Cambridge University Press 2010).

${ }^{8}$ Such as the response to the above cited work by Barron in Jonathan Aldred, 'Copyright and the Limits of Lawand-Economics Analysis' in Lionel Bently, Jennifer Davis and Jane C Ginsburg (eds), Copyright and Piracy: An interdisciplinary critique (Cambridge University Press 2010); see also William F Patry, How to Fix Copyright (Oxford University Press 2011).

${ }^{9}$ Such as RM Hilty and others, 'Comment by the Max-Planck Institute on the Commission's Proposal for a Directive to Amend Directive 2006/116 Concerning the Term of Protection for Copyright and Related Rights' (2009) 31(2) European Intellectual Property Review 59 on whether the term of protection for sound recordings should have been extended to 70 years post-publication in the EU.

10 See for example the works of Laurence R Helfer and Graeme W Austin, Human Rights and Intellectual Property: Mapping the Global Interface (Cambridge University Press 2011); and Duncan Matthews, Intellectual Property, Human Rights and Development: The Role of NGOs and Social Movements (Edward Elgar Publishing Ltd 2012); as well as the edited volumes edited by Paul LC Torremans (ed), Intellectual Property and Human Rights: Enhanced Edition of Copyright and Human Rights (Kluwer Law International 2008); and Christophe Geiger, Research Handbook on Human Rights and Intellectual Property (Edward Elgar Publishing Ltd 2016).

11 The Universal Declaration of Human Rights (1948), preamble paragraph 1
} 
considerable debate and contestation during the drafting of the Universal Declaration, ${ }^{12}$ it was nevertheless incorporated into the final text 'by those who felt the ongoing internationalization of copyright needed a boost and that this could be a tool in this respect'. ${ }^{13}$

As readers will no doubt be aware, however, the Universal Declaration is not directly legally binding, ${ }^{14}$ instead serving as the basis for future international law making. Other covenants are legally binding, however, such as the International Covenant on Economic, Social and Cultural Rights, or ICESCR. ${ }^{15}$ The ICESCR mirrors the language of the Universal Declaration, stating at Article 15(1)(c) that states recognise the right of everyone to 'benefit from the protection of the moral and material interests resulting from any scientific, literary or artistic production of which he is the author'. Most of the world is now party to the ICESCR, with the notable exception of the United States, which, while signing the Covenant, did not ratify, with the views of US administrations ranging from perceiving the concept of the rights reflected in the ICESCR as being 'socialist' during the height of the Cold War, ${ }^{16}$ to being 'socially desirable goals' to strive towards rather than binding rights, ${ }^{17}$ to most recently the Obama administration stating the importance of human rights, but not committing to ratification of the ICESCR. ${ }^{18}$ With regard to the treatment of intellectual property generally, and indeed copyright specifically, the US legal regime provides for no specific protection of these rights as any kind of human right, instead affording Constitutional protection under Article 1, Section 8, Clause 8, empowering Congress to 'promote the Progress of Science and useful Arts, by securing for limited Times to Authors and Inventors the exclusive Right to their respective Writings and Discoveries'. In this, it may be seen that the protection afforded to copyright in the US is on the basis of a consequentionalist line of reasoning, in

\footnotetext{
12 Paul LC Torremans, 'Copyright as a Human Right' in Paul LC Torremans (ed), Copyright and Human Rights: Freedom Of Expression, Intellectual Property, Privacy (Kluwer Law International 2004) 5-6; see also Helfer and Austin (n 11) 176-180.

13 Torremans (n 13) 6.

14 Mihály Ficsor, 'Collective Management and Multi-Territorial Licensing: Key Issues of the Transposition of Directive 2014/26/EU' in Irini A Stamatoudi (ed), New Developments in EU and International Copyright Law (Kluwer Law International 2016) 220.

15 International Covenant on Economic, Social and Cultural Rights (1966)

${ }^{16}$ See for example Helen M Stacy, Human Rights for the 21st Century: Sovereignty, Civil Society, Culture (Stanford University Press 2009).

17 Patrick J Austin, 'Expansive Rights: FDR's Proposed “Economic” Bill of Rights Memorialized in the International Covenant on Economic, Social and Cultural Rights, But with Little Impact in the United States' (2015) XV Chicago-Kent Journal of International and Comparative Law 1, 23.

18 Judith Blau, 'Human Rights: What the United States Might Learn from the Rest of the World And, Yes, from American Sociology' (2016) doi:10.1111/socf.12299 Sociological Forum 1, 2.
} 
which it is for the benefits that the dissemination of works accrues that it is protected, rather than on specific human rights grounds. ${ }^{19}$ According to Blau, human rights-based discourses do not feature prominently in US politics, with US citizens neither clear nor convinced of the relevance of such approaches to legal protection, particularly in comparison to the EU, where such understandings have been mainstreamed. ${ }^{20}$ It is perhaps unsurprising, then, that the majority of discussion of copyright in human rights terms, and indeed law-making along such lines, has taken place in Europe. For this reason, the analysis that will be conducted of the balancing of human rights obligations impacted by copyright will focus upon actions and jurisprudence at the EU level.

The European Convention on Human Rights (ECHR), the international treaty to which all Council of Europe member states are party, also appears to provide for intellectual property protection as a human right. For clarity, it is worth reiterating that the Council of Europe, the ECHR and the ECtHR are not institutions of EU law, but intergovernmental agreement outwith the EU legal framework. Under Article 1 of Protocol 1, 'every natural or legal person is entitled to the peaceful enjoyment of his possessions'. Whether this applied to 'intellectual' property as well as physical property was uncertain, with the European Court of Human Rights (ECtHR) and European Commission on Human Rights avoiding consideration of intellectual property-related issues. ${ }^{21}$ However, the ECtHR has concluded that the protection of intellectual property rights, be they copyright, patent or trade mark, 'incontestably enjoys the protection of Article 1 of Protocol 1'.22 This decision was confirmed in Anheuser-Busch $v$ Portugal in 2007, in which the Grand Chamber stated that it agreed 'with the [trial] Chamber's conclusion that Article 1 of Protocol No. 1 is applicable to intellectual property as such'. ${ }^{23}$ For some time, it had appeared that the EU would become a party to the ECHR. The EU was expected to join the ECHR after the entry into force of the Treaty of Lisbon, as written in Article 6 of the Treaty on European Union (TEU). However, in Opinion 2/1324 of the European Court of Justice, sitting as a full court, it was determined that the agreement

\footnotetext{
${ }^{19}$ Helfer and Austin (n 11) 174-175.

20 Blau (n 19) 7.

${ }^{21}$ Laurence R Helfer, 'The New Innovation Frontier? Intellectual Property and the European Court of Human Rights' (2008) 49 Harvard International Law Journal 1, 3.

${ }^{22}$ Anheuser-Busch Inc. v. Portugal, [2005] ECHR 686 (11 October 2005),

${ }^{23}$ Anheuser-Busch Inc. v. Portugal, [2007] ECHR 40 (11 January 2007), para.72 of the judgement

${ }^{24}$ Opinion 2/13 Opinion of the Court (Full Court) of 18 December 2014 EU:C:2014:2454
} 
formulated to achieve this accession was not compatible with EU law, particularly regarding the autonomy of EU law, a decision considered 'regrettable' by Storgaard. ${ }^{25}$

Despite this, however, the EU has nevertheless constituted the ECHR as part of its constitutional order through using it in the construction of its own approach to fundamental rights as constituting general principles of EU law. ${ }^{26}$ Arguments that it should appear based on a belief that 'a human right to one's creative productions arguably casts new emphasis on the role and vulnerabilities of individual creators' ${ }^{27}$ Geiger, for example, argues that the consideration of copyright protection in human rights (or fundamental rights) terms is to be welcomed, and can serve as the basis for a constitutionalisation of intellectual property law. ${ }^{28}$ Furthermore, it has provided for its own recognition of intellectual property protection as a 'fundamental right' under the EU's Charter on Fundamental Rights ${ }^{29}$. Under Article 17's 'right to property', which states at Article 17(1) that everyone 'has the right to own, use, dispose of and bequeath his or her lawfully acquired possessions', Article 17(2) rather perfunctorily states that 'intellectual property shall be protected'. This protection, it must be noted, is based upon Article 1 of Protocol 1 of the ECHR, with intellectual property being mentioned specifically and separately due to its 'growing importance and Community secondary legislation'. ${ }^{30}$ In comparison to the US, then, the EU appears to be clear in its understanding that copyright, as well as an economic right, can also constitute a human right.

\section{STRIKING A FAIR BALANCE: - THE DECISIONS OF THE EUROPEAN COURT OF JUSTICE}

\footnotetext{
${ }^{25}$ LH Storgaard, 'EU Law Autonomy versus European Fundamental Rights Protection - On Opinion 2/13 on EU Accession to the ECHR' (2015) 15 Human Rights Law Review 485, 499.

26 Tuomas Mylly, 'The Constitutionalization of the European Legal Order' in Christophe Geiger (ed), Research Handbook on Human Rights and Intellectual Property (Edward Elgar 2015) 105.

27 Helfer and Austin (n 11) 180.

${ }^{28}$ See generally Christophe Geiger, “'Constitutionalising” Intellectual Property Law? The Influence of Fundamental Rights on Intellectual Property in the European Union' (2006) 37 International Review of Intellectual Property and Competition Law 371; see also Megan M Carpenter, 'Intellectual Property: A Human (Not Corporate) Right' in David Keane and Yvonne McDermott (eds), The Challenge of Human Rights: Past, Present and Future (Edward Elgar Publishing Ltd 2012); for a critique of this reasoning, Jonathan Griffiths and Luke McDonagh, 'Fundamental Rights and European IP Law - the Case of Art 17(2) of the EU' in Christophe Geiger (ed), Constructing European Intellectual Property: Achievements and New Perspectives (Edward Elgar 2013).

${ }^{29}$ Charter on the Fundamental Rights of the European Union [2012] OJ C 326/391

${ }^{30}$ Explanations relating to the Charter of Fundamental Rights [2007] OJ C 303/17, 303/23
} 
Perhaps at the forefront of discussions on copyright and human rights on the Internet has been the issues of privacy ${ }^{31}$ and freedom of expression, ${ }^{32}$ particularly as it pertains to copyright enforcement, as well as the right to expression. At the outset, it must be made clear that the TRIPS Agreement makes no reference to the balancing of the protection of copyright with other human rights obligations. In the EU, the Information Society Directive, ${ }^{33}$ the main Directive concerning copyright protection on the Internet, does not deal with privacy or expression directly as concepts in conflict with copyright protection. Instead, it makes brief references to the notion, stating in its non-legally binding recital 3 that copyright protection will help facilitate freedom of expression, and at recital 57 that the use of Technological Prevention Measures used to protect copyright, such as rightsmanagement information systems that gather data on users of digital works, should incorporate privacy safeguards as provided for in the Data Protection Directive ${ }^{34}$. Furthermore, under Article 9, where it was stated that the Directive does not prejudice earlier legal provisions, including those pertaining to data protection and privacy. The Enforcement Directive ${ }^{35}$, passed in 2004 and intended to facilitate effective protection of intellectual property rights through ensuring access to information regarding individuals alleged to be engaging in infringement ${ }^{36}$, refers in recital 2 to the fact that the measures contained 'should not hamper [...] the protection of personal data, including on the Internet', but not to privacy as a fundamental right. What it does reference, interestingly, is the fundamental rights dimension of intellectual property protection, by stating that the Directive respects the fundamental rights [...] recognised by the Charter [...] in particular, [it] seeks to ensure full respect for intellectual property, in accordance with Article 17(2) of that Charter'. 37

\footnotetext{
${ }^{31}$ Recognised as a fundamental right under Article 8 of the ECHR, and under Article 7 of the Charter of Fundamental Rights, with Article 8 providing protection for personal data.

32 Article 10 of the ECHR, and Article 11 of the Charter of Fundamental Rights

33 Directive 2001/29/EC on the harmonization of certain aspects of copyright and related rights in the information society

${ }^{34}$ Directive 95/46/EC on the protection of individuals with regard to the processing of personal data and on the free movement of such data, which is due to be replaced in 2018 by the new Regulation 2016/679 on the protection of natural persons with regard to the processing of personal data and on the free movement of such data, which was adopted in April 2016.

35 Directive 2004/48/EC on the enforcement of intellectual property rights

36 Ibid, Article 8

37 Ibid, recital 32
} 
The requirement to achieve a balance between competing rights was first established in the case of Promusicae. ${ }^{38}$ This case concerned the right to information under Article 8 of the Enforcement Directive, and whether an Internet Service Provider (ISP) was obliged to provide personal information regarding an alleged copyright infringer. According to Promusicae, a trade organisation representing the recorded music industry in Spain, ISPs had a legal requirement under the Enforcement Directive to provide information such as the name and address of users of the KaZaA peer-to-peer software alleged to be infringing copyright through sharing copies of copyrighted music. Telefónica, the ISP, instead claimed that it was only authorised by Spanish law to provide this information to facilitate investigations into criminal conduct in order to safeguard public security, not either in or proceeding civil investigations. In its preliminary ruling, the CJEU concluded that while Article 8 of the Enforcement Directive does require Member States to ensure that national judicial authorities may be able to order that information concerning infringement be provided, it did not necessarily follow that, in order to ensure effective protection of copyright, this imposed 'an obligation to communicate personal data in the context of civil proceedings'. ${ }^{39}$ Furthermore, the CJEU considered this case in light of fundamental rights, considering that Member States must 'take care to rely on an interpretation of the directives which allows a fair balance to be struck between the various fundamental rights protected by the Community legal order'. ${ }^{40}$ In this case, this required a balancing of the fundamental right to respect of intellectual property, and the protection of personal data 'and hence of private life'. ${ }^{41}$

Promusicae was then followed by several judgements concerned with copyright protection on the Internet, each of which reiterated this principle and the need for ensuring the striking of a 'fair balance' between these fundamental rights. In two closely linked cases, Scarlet $v$ $S A B A M^{42}$ and $S A B A M v N e t \log ^{43}$, the CJEU was asked to determine whether requests by SABAM, a collective rights management organisation in Belgium, to require Scarlet, an ISP, to end copyright infringement by users of its service. SABAM proposed a system in which

\footnotetext{
${ }^{38}$ Case C-275/06 Productores de Música de España (Promusicae) v Telefónica de España SAU EU:C:2008:54

39 Ibid, para.58

40 Ibid, para.68

41 Ibid, para.63

42 Case C-70/10 Scarlet Extended SA v Société belge des auteurs, compositeurs et éditeurs SCRL (SABAM) EU:C:2011:771

43 Case C-360/10 SABAM v Netlog NV EU:C:2012:85
} 
Scarlet would make it impossible for its customers to send or receive copyright infringing files by way of peer-to-peer file-sharing software, on the basis that it considered the ISP 'best placed [...] to take measures to bring to an end copyright infringements committed by its customers'. ${ }^{44}$ The CJEU concluded that in order to prevent infringing activities from taking place in the way SABAM requested, a preventative monitoring system would need to be created that would identify files related to peer-to-peer traffic, and indeed whether those files contained content protected by copyright, in order to block that infringing activity. Such a system was declared incompatible with Article 15 of the E-Commerce Directive, ${ }^{45}$ which states that Member States shall not impose an obligation upon ISPs to actively monitor the information that they transmit or store. ${ }^{46}$ Furthermore, the CJEU considered that such a system would raise serious privacy concerns, as it would necessitate analysing all information to be transmitted and all customers using that network. ${ }^{47}$ While acknowledging that copyright protection constitutes a fundamental right under Article 17(2) of the Charter, the CJEU argued that there was nothing in that provision to indicate that the 'right is inviolable and must for that reason be absolutely protected'. ${ }^{8}$ Therefore, following Promusicae, it was necessary to ensure that a fair balance was struck between the protection of copyright as a fundamental right, and the right to protection of personal data and private life under Article 8 of the Charter, as well as the freedom to receive and impart information under Article $11 .{ }^{49}$ In the proposed system, this balance would not be struck. ${ }^{50}$ The reasoning in Netlog was much briefer, but followed directly from Scarlet. Netlog was not an ISP, but a social media platform, similar in function to Facebook. In this case, SABAM requested the same filtering system be activated, but in this instance by the owners of the Netlog platform, rather than the ISP. The CJEU reiterated its decision from Scarlet, stating the need for a balance to be struck, and that such a preventative monitoring system would be incompatible to the right to privacy under Article 8 of the Charter, as well as the freedom to receive or impart information under Article 11.51

\footnotetext{
44 Scarlet (n42), para.18

${ }^{45}$ Directive 2000/31/EC on certain legal aspects of information society services, in particular electronic commerce, in the Internal Market

46 Scarlet (n42), para.40

47 Ibid, para.39

48 Ibid, para. 43

49 Ibid, para.50

50 Ibid, para.53

${ }^{51}$ Netlog $(\mathrm{n} 43)$ para.48
} 
The interpretation of the effect of these decisions has been considerably broad. While Hugenholtz states that these decisions make it clear that copyright protection must be balanced with other fundamental rights such as privacy and freedom of expression, ${ }^{52}$ the extent to which this may be considered an explicit recognition of, and indeed desire to protect, fundamental rights is disputed; whereas citizens' rights organisations such as EDRi (European Digital Rights) considered these decisions to constitute a 'vital victory for Internet freedoms', ${ }^{53}$ not all academics have been so convinced of an express human rights rationale. Griffiths, for example, argues that the human rights arguments raised in cases such as Scarlet and Netlog did not reflect a desire by the Court to expressly balance competing human rights obligations, but instead reinforce a decision already made on the basis of specific Directives, albeit in a way that expanded the Court's competence. ${ }^{54}$ Regardless of underlying motive, however, it is clear that in the jurisprudence of the CJEU, the understanding is that copyright and other fundamental freedoms may be in conflict, requiring a balancing of those competing obligations. This has been further reflected in cases such as GS Media, ${ }^{55}$ where it was concluded that hyperlinking to content online would only constitute copyright infringement where it was communicated to a 'new' public by means of circumventing password protection or other TPMs, ${ }^{56}$ and if the alleged infringer was likely to have knowledge that their act constituted an infringement. ${ }^{57}$ On the issue of fundamental rights, the Court stated that:

[It] should be noted that the internet is in fact of particular importance to freedom of expression and of information, safeguarded by Article 11 of the Charter, and that hyperlinks contribute to its sound operation as well as to the exchange of opinions and information in that network characterised by the availability of immense amounts of information. 58

\footnotetext{
52 P Bernt Hugenholtz, 'Flexible Copyright: Can EU Author's Rights Accommodate Fair Use?' in Irini A Stamatoudi (ed), New Developments in EU and International Copyright Law (Kluwer Law International 2016) 432.

53 EDRI, 'Scarlet v SABAM: A Win for Fundamental Rights and Internet Freedoms' (EDRI, 30 November 2011) <http://www.edri.org/edrigram/number9.23/scarlet-sabam-win-fundamental-rights> accessed 7 August 2013.

54 Jonathan Griffiths, 'Constitutionalising or Harmonizing? The Court of Justice, the Right to Property and European Copyright Law' (2013) 38 European Law Review 65.

55 Case C-160/15 GS Media BV v Sanoma Media Netherlands and Others EU:C:2016:644

56 Following Case C-466/12 Svensson v Retriever Sverige AB EU:C:2014:76

57 GS Media (n55) paras.48-49

58 ibid, para. 45
} 
Similarly in the case of UPC Telekabel ${ }^{59}$, which considered whether IP blocking regimes that prevented users from accessing websites making available copyright infringing materials were contrary to principles of fundamental rights, that the protection of copyright as a fundamental right had to be balanced with the protection of fundamental rights such as those to conduct a business or access information. ${ }^{60}$ Noting that there was 'nothing whatsoever in the wording of Article 17(2) of the Charter to suggest that the right to intellectual property is inviolable and must for that reason be absolutely protected', 61 the CJEU nevertheless concluded that blocking orders would nevertheless be viewed as proportionate where they are specifically targeted and 'do not unnecessarily deprive internet users of the possibility of lawfully accessing the information available'. ${ }^{62}$ The CJEU has therefore developed a line of case law that is explicit on two points: - 1) that copyright protection constitutes a fundamental right, deserving of protection under the EU Charter, and 2) that its protection may potentially come into conflict with other fundamental rights, requiring a balancing of those competing obligations. That this conflict between copyright protection and other fundamental rights exists, and is a conflict that requires balancing, is something that has been recognised and adopted by other EU institutions such as the European Commission. For example, in the December 2015 Communication on 'Towards a modern, more European copyright framework', 63 the Commission stated that while copyright requires civil enforcement mechanisms, they should 'take full account of fundamental rights'.64 Whether the proposed reforms to enforcement achieve this, however, is something that is not yet known, as at the time of writing the Commission's approach to this issue has not yet been published.

\section{COPYRIGHT AS THE ENGINE OF EXPRESSION: - FIRST AMENDMENT CONSIDERATIONS IN THE UNITED STATES}

Unlike the thrust of the case law in the EU, disputes concerning the balancing of copyright protection with other rights are not framed in human rights terms in the US. While the jurisprudence at times deals with similar issues, they are framed by constitutional rather

\footnotetext{
${ }^{59}$ Case C-314/12 UPC Telekabel v Constantin Film Verleih GmbH EU:C:2014:192

60 Ibid, para.46

61 Ibid, para. 61

62 Ibid, para.63

63 European Commission, 'Towards a Modern, More European Copyright Framework' (2015) COM(2015) 626.

64 ibid 11.
} 
than fundamental rights discourses. As stated above, copyright protection is afforded constitutional protection in the US, on the basis of a consequentionalist reasoning that dictates protection is granted in order to facilitate socially beneficial progress in the arts and sciences. In comparison to the EU, there is no specifically stated constitutional status afforded to the right of privacy in the US, and privacy ultimately receives little legal protection. ${ }^{65}$ Indeed, while the Supreme Court in the case of Griswold $v$ Connecticut ${ }^{66}$ declared that there is an implied constitutional protection of privacy by way of the First Amendment 67 , which 'has a penumbra where privacy is protected from governmental intrusion'.68 This right of privacy has been applied in cases such as Roe $v$ Wade $^{69}$, regarding a woman's right to a termination of pregnancy. However, as Strahilevitz argues, this protection is limited in its efficacy, 'largely because judges have chosen to interpret the First Amendment in a way that places privacy and speech interests at loggerheads'. ${ }^{70}$ Furthermore, according to Shiffrin, protections for privacy in the US are rooted in protecting the liberty of individuals against government tyranny, 'rather than against violations of dignity by the media or the market'. ${ }^{71}$ Indeed, as the First Amendment states, 'Congress shall make no law respecting an establishment of religion, or prohibiting the free exercise thereof; or abridging the freedom of speech, or of the press'. The target of this principle is lawmakers, rather than individuals or organisations, raising questions as to whether individuals can rely upon the First Amendment in horizontal disputes with other individuals. In the context of copyright law, this perception of two rights at 'loggerheads', namely privacy and freedom of expression, appears credible.

In fact, given the comparatively meagre privacy protection given to those in the public eye in the US, including politicians and celebrities, ${ }^{72}$ it is perhaps no surprise that the use of copyright as a means of protecting privacy rights otherwise given short thrift by the courts has been attempted. Some of the earlier cases considering the interaction between copyright

\footnotetext{
65 Lior Jacob Strahilevitz, 'Toward a Positive Theory of Privacy Law' (2013) 126 Harvard Law Review 2010, 2012.

66 Griswold v Connecticut 381 US 479 (1965)

${ }^{67}$ In addition to others, such as the Fifth Amendment concerning self-incrimination; for the purposes of this chapter, however, the main focus is upon the First Amendment.

68 Ibid 483

${ }^{69}$ Roe v Wade 410 US 113 (1973)

${ }^{70}$ Strahilevitz (n 66) 2013.

${ }^{71}$ Steven H Shiffrin, What's Wrong with the First Amendment (Cambridge University Press 2016) 23.

72 See generally Scott J Shackelford, 'Fragile Merchandise: A Comparative Analysis of the Privacy Rights for Public Figures' (2012) 49 American Business Law Journal 125.
} 
and freedom of speech under the First Amendment were in fact cases in which the dispute was over rights to privacy in conflict with free speech, in which copyright protection was not at the centre of the conflict, but the means by which other rights were being protected. ${ }^{73}$ For example, in the Random House case ${ }^{74}$, the Second Circuit of the Court of Appeal was asked to intervene in a dispute between Howard Hughes, an entrepreneur known for his eccentric and reclusive lifestyle, and John Keats, writer of an unauthorised biography. Seeking to protect his privacy and prevent certain details of his life becoming public, Hughes had purchased the copyright over a series of articles called 'The Howard Hughes Story', upon which John Keats had drawn considerably in writing his biography. Placing freedom of speech above privacy, the Court concluded that the use of the material from the biographies was fair use, ${ }^{75}$ a 'privilege in others than the owner of a copyright to use copyrighted material in a reasonable manner without his consent'76, and that on occasion the interest of a copyright holder may be subordinated to 'the greater public interest in the development of art, science and industry'. ${ }^{77}$ Given the comparatively little judicial weight given to privacy in the US, more attention has been given to the interaction between copyright and First Amendment rights to speech.

In comparison to the EU, where the interaction between the protection of copyright and freedom of expression is seen as one of balancing between separate and distinct rights, in the US, 'contemporary jurisprudence is not one that balances free speech considerations against other interests [...and] does not weight the free speech rights of one party against the copyright rights of the other party'. ${ }^{78}$ Instead, if copyright is perceived as interfering with free speech, it is to be analysed internally, determining whether copyright itself is compliant with the First Amendment. In Harper \& Row $^{79}$, the US Supreme Court considered the interaction between copyright and the First Amendment, determining that not only was

\footnotetext{
${ }^{73}$ Benjamin Farrand, 'Regulatory Capitalism, Decentred Enforcement and Its Legal Consequences for Digital Expression: - The Use of Copyright Law to Restrict Freedom of Speech Online' (2013) 10 Journal of Information Technology and Politics 404, 412.

${ }^{74}$ Rosemont Enterprises Inc. $v$ Random House Inc. 366 F.2d 303 (2d Cir. 1966)

7517 US Code $\S 107$, which allows for the use of a work protected by copyright, subject to an assessment by a court regarding whether that use is fair, taking into account aspects such as the nature of the use, the nature of the copyrighted work, the amount and substantiality of the use as a portion of the original work, and whether such use is commercial in nature.

${ }^{76}$ Ibid para.13

77 Ibid

78 Michael D Birnhack, 'Copyright Speech: A Transatlantic View' in Paul Torremans (ed), Copyright and Human Rights: Freedom Of Expression, Intellectual Property, Privacy (Kluwer Law International 2004) 41-42.

${ }^{79}$ Harper \& Row Publishers v Nation Enterprises 471 US 539 (1985)
} 
copyright First Amendment compatible, but that it acted to serve the interests of the First Amendment. Referring to the drafting of the Constitution, the Supreme Court argued that the 'framers intended copyright itself to be the engine of free expression. By establishing a marketable right to the use of one's expression, copyright supplies the economic incentive to create and disseminate ideas' ${ }^{80}$ In other words, the Supreme Court has held that there is no need to scrutinise copyright's compatibility with the First Amendment, as both ultimately serve the same goal, namely that of facilitating speech. ${ }^{81}$ The Supreme Court reiterated this in the case of Eldred $v$ Ashcroft, 82 a case concerned with the duration of copyright, and an appeal against the term of protection being extended to the life of the author plus seventy years. In this case, the Supreme Court referred to Harper \& Row, stating that 'copyright law contains built-in First Amendment protections', ${ }^{83}$ referring once again to the fair use doctrine. While over-protection of copyright may potentially conflict with free speech, the internal conflict is mediated through reliance upon fair use in a court when accused of an act of infringement. ${ }^{84}$ In Golan $v$ Holder ${ }^{85}$, this was again affirmed, finding that there was no conflict. ${ }^{86}$ A number of scholars have supported this position, such as Eisgruber, who has argued that 'copyright is not censorious [and it] does not pick and choose among ideas and subject-matters', 87 and Nimmer, who argued that while the First Amendment serves to protect speech, copyright then works to disseminate it; any potential hindrance to freedom of speech is 'far out-balanced by the public benefit that accrues through copyright encouragement of creativity'. ${ }^{88}$ Such a perception, it is submitted, is based on the view that rather than having the potential to censor, copyright instead serves as a tool for the exchange of ideas. ${ }^{89}$

\footnotetext{
80 Ibid 558, emphasis added by the author

81 Melville B Nimmer, 'Does Copyright Abridge the First Amendment Guarantees of Free Speech and Press' (1969) 17 UCLA Law Review 1180; William McGinty, 'First Amendment Rights to Protected Expression: What Are the Traditional Contours of Copyright Law?' (2008) 23 Berkeley Technology Law Journal 1099.

${ }^{82}$ Eldred $v$ Ashcroft 537 US 186 (2003)

83 Ibid 219

${ }^{84}$ It must be stated that fair use is not a 'proactive' right that can be enforced, but is a defence to an accusation, as discussed generally in Pierre N Leval, 'Toward a Fair Use Standard' (1990) 103 Harvard Law Review 1105.

85 Golan v Holder 132 S Ct 873 (2012)

86 Ibid 890

87 Christopher L Eisgruber, 'Censorship, Copyright and Free Speech: Some Tentative Skepticism About the Campaign to Impose First Amendment Restrictions on Copyright Law' (2003) 2 Journal on Telecommunications and High Technology Law 17, 18.

88 Nimmer (n 82) 1192.

89 Thomas F Cotter, ‘Gutenberg's Legacy: - Copyright, Censorship and Religious Pluralism' (2003) 91(2) California Law Review 323, 328.
} 
Yet such an approach is too focused upon the role of the state as censor, which is understandable given the nature of the First Amendment as a check on governmental power. ${ }^{90}$ However, on the Internet, media and market power complement, and in some respects, supplant the power of the state. ${ }^{91}$ Timothy Garton Ash refers to the Internet's private superpowers, companies such as Google, Facebook, Twitter, Intel, Oracle, Cisco and Wikipedia. ${ }^{92}$ Yet it is not only these Internet intermediary service providers that wield considerable power on the Internet, but traditional copyright industries such as the media, record labels and movie studios have also been empowered. Through a process of online intermediarisation, the decision whether actions on the Internet are considered to be a fair use of a work no longer resides in a judicial assessment, but an administrative exercise performed by a private undertaking such as Google or Facebook. ${ }^{93}$ Under the Digital Millennium Copyright Act (DMCA) of 1998,94 a service provider shall not be deemed liable for copyright infringement for material transferred through the Internet connection or stored on a computer system, so long as it removes or restricts access to the infringing content upon receiving a request from the copyright holder. Through a system known as 'notice and takedown', should an allegation of infringement be made to a service provider such as YouTube, saying that a video contains infringing content, under the DMCA that service provider is obliged to remove that infringing content. Where that removed content is a direct copy of a work, such as a song from an album uploaded to YouTube without the permission of the copyright holder, in principle there would be no First Amendment concern; the right to free speech does not include the right to pirate someone else's work, ${ }^{95}$ or as it was put in Eldred $v$ Aschroft, to 'make other people's speeches'. ${ }^{96}$

However, in more complex cases, there is the risk that notice and takedown in the absence of judicial assessment may lead to conflicts with free speech, such as where a transformative work such as a mash-up, in which two songs are remixed together in a way to create a new,

\footnotetext{
90 Eisgruber (n 88) 18; Neil Weinstock Netanel, Copyright's Paradox (Oxford University Press 2008) 35.

${ }^{91}$ See for example Niva Elkin-Koren and Eli M Salzberger, Law, Economics and Cyberspace: The Effects of Cyberspace on the Economic Analysis of Law (Edward Elgar 2004); Angela Daly, Private Power, Online Information Flows and EU Law: Mind the Gap (Hart Publishing 2016).

92 Timothy Garton Ash, Free Speech: Ten Principles for a Connected World (Main edition, Atlantic Books 2016) 21.

93 See generally Farrand (n 74).

9417 US Code $§ 512$

95 Mark A Lemley and Eugene Volokh, 'Freedom of Speech and Injunctions in Intellectual Property Cases' (1998) 48 Duke Law Journal 147, 211-212; Rebecca Tushnet, 'Copy This Essay: How Fair Use Doctrine Harms Free Speech and How Copying Serves It' (2004) 114 The Yale Law Journal 535, 567.

${ }^{96}$ Eldred v Ashcroft (n 82) 191
} 
original work, is removed from YouTube, ${ }^{97}$ or where a video of a dancing baby is removed because of the inclusion of the music to which the baby was dancing. ${ }^{98}$ In the second case, the uploader of the video sued Universal Music Group (UMG) for misrepresentation of a DMCA claim, arguing that UMG acted in bad faith, as the entity would have been aware that such a use would be fair. ${ }^{99}$ While the District Court found in the uploader's favour, it was not until the appeal heard by the Ninth Circuit of the Court of Appeal in 2015,100 eight years later, that the court affirmed that the video was fair use. While reiterating that fair use was a defence rather than cause of action, the Court of Appeal nevertheless concluded that 'duty to consider, in good faith and prior to sending a takedown notification, whether allegedly infringing material constitutes fair use'. ${ }^{101}$ It must be stated that the First Amendment was not mentioned at any point in the decision of the District Court, nor in the Court of Appeal. It would appear that, at least in the eyes of the Court, there is still no (officially recognised) conflict. Nevertheless, scholars have argued that the DMCA and the system of notice and takedown do have a noticeable 'chilling effect', 102 as noted by Hon. McKeown, a judge of the Ninth Circuit Court of Appeal. In an address to the Chicago-Kent Supreme Court IPR, republished as an article, McKeown stated that 'copyright has become a go-to tool to prevent the spread of damaging or offensive information on the Internet'. ${ }^{103}$ Examples include the use claims of copyright infringement to remove Wikileaks disclosure of US diplomatic cables, embarrassing internal memos by Citigroup praising austerity as good for business after receiving considerable bailouts, and the use of takedown requests to suppress election campaign videos on YouTube by rival camps. ${ }^{104}$ In the absence of effective privacy protection, McKeown argues, copyright law becomes a surrogate. ${ }^{105}$ While copyright may be seen as the engine of expression, and fair use its safety valve, in the absence of strong human

\footnotetext{
${ }^{97}$ See generally Andrew S Long, 'Mashed Up Videos and Broken Down Copyright: Changing Copyright to Promote the First Amendment Values of Transformative Video' (2007) 60 Oklahoma Law Review 317. ${ }_{98}$ Lawrence Lessig, Remix: Making Art and Commerce Thrive in the Hybrid Economy (Avery Publishing 2008) 23; Samantha Von Hoene, 'Fair Use in the Classroom; A Conundrum for Digital User-Generated Content in the Remix Culture' (2015) 7 Hastings Science and Technology Law Journal 97.

${ }^{99}$ Lenz v Universal Music Group, 572 F. Supp. 2d 1150 (2007)

100 Lenz v Universal Music Group, 801 F.3d 1126 (2015)

101 Ibid, 1138

102 Kaminski Margot, 'Copyright Crime and Punishment: The First Amendment's Proportionality Problem' (2013) 73 Maryland Law Review 587; see also Wendy Seltzer, 'Free Speech Unmoored in Copyright's Safe Harbor: Chilling Effects of the DMCA on the First Amendment' (2010) 24 Harvard Journal of Law \& Technology 171.

103 M Margaret McKeown, 'Censorship in the Guise of Authorship: Harmonizing Copyright and the FIrst Amendment' (2016) 15 Chicago-Kent Journal of Intellectual Property 1, 11.

104 Farrand (n 74) 415-419 for more on these examples.

105 McKeown (n 104) 14-15.
} 
rights norms, there remains an uneasy tension in the apparent 'no conflict' approach of US jurisprudence.

\section{SEEING THINGS DIFFERENTLY: - CITIZEN PARTICIPATING IN LAW-MAKING WHERE BALANCE IS NOT FOUND, OR RIGHTS ARE IN CONFLICT}

Whether a fine-tuned balance, as perceived by the judges of the CJEU, or an internal conflict (or indeed denial of conflict) resolved by recourse to the principle of fair use, as in the US, the compatibility of copyright protection with human rights online is increasingly a contested political debate. ${ }^{106}$ With the increase in concern over the existence of 'digital rights', ${ }^{107}$ Internet users become activists, forming 'issue networks', in which they collaborate to raise awareness and challenge what they perceive as threats to these online freedoms, in particular where they concern privacy and freedom of speech. ${ }^{108}$ We have seen such protests throughout the EU and the US, albeit taking somewhat different forms, and focused upon different fundamental rights issues. Considering these developments chronologically (as the two phenomena are linked), it is best to consider the US first. Due to the perceived ineffectiveness of the established 'notice and takedown' system, two Bills with similar subject matter were announced in 2011, one in the House of Representatives, the other in the Senate. In the House, a Bill called the Stop Online Piracy Act (SOPA) ${ }^{109}$ was introduced by Representative Lamar Smith, and in the Senate, the PROTECT IP Act (PIPA) ${ }^{110}$ by Senator Patrick Leahy. Both proposals were considered to be heavily lobbied for by copyright industries, including the Recording Industry Association of America, and the Motion Picture Association of America. ${ }^{111}$ SOPA $^{112}$ contained provisions that would allow for immunity from liability of an Internet intermediary service provider for voluntarily blocking

\footnotetext{
106 See for example Bill D Herman, The Fight over Digital Rights: The Politics of Copyright and Technology (Cambridge University Press 2013); Benjamin Farrand, Networks of Power in Digital Copyright Law and Policy: Political Salience, Expertise and the Legislative Process (Routledge 2014).

107 See for example Lawrence Lessig, Code 2.0 (Basic Books 2006); Rebecca MacKinnon, Consent of the Networked: The Worldwide Struggle for Internet Freedom (Basic Books 2012).

108 On Internet users as activists in issue networks, see Milton Mueller, Networks and States: The Global Politics of Internet Governance (MIT Press 2010); on protest as a form of civic engagement Ken Kollman, Outside Lobbying: Public Opinion and Interest Group Strategies (Princeton University Press 1998).

109 Stop Online Piracy Act, HR.3261, 112 th Congress (2011-2012)

110 PROTECT IP Act, S.968, 112 $2^{\text {th }}$ Congress (2011-2012)

111 Christian Yoder, 'A Post-SOPA (Stop Online Piracy Act) Shift in International Intellectual Property Norm Creation' (2012) 15 The Journal of World Intellectual Property 379, 378; see also Susan K Sell, 'Revenge of the "Nerds": Collective Action against Intellectual Property Maximalism in the Global Information Age' (2013) 15 International Studies Review 67, 79.

112 In the interests of brevity, and given the similarity of the two documents, this chapter will focus on the substantive provisions of SOPA alone.
} 
foreign websites (i.e. websites with a non-US based IP address) ${ }^{113}$ believed to be infringing IP rights, allowing for the Attorney General to order the blocking of websites believed to be infringing IP rights, ${ }^{114}$ as well as making it illegal to stream infringing copyrighted works. ${ }^{115}$ According to Minnock, these provisions raised considerable First Amendment concerns, including the right of US citizens to 'read and listen to foreign speech'.116 According to the EFF, while ostensibly intended to target sites allowing for indiscriminate piracy of copyrighted works, SOPA's vaguely defined notion of 'foreign website' could include services such as Rapidshare and Dropbox, as well as sites discussing piracy such as TorrentFreak, and sites featuring user-generated content such as Deviant Art or Sound Cloud, which may incorporate elements of a copyrighted work in a way constituting fair use. EFF concluded by stating that 'had these bills been passed five or ten years ago, even YouTube might not exist today'.117

Despite judicial understanding that copyright poses no First Amendment conflict, and that fair use serves as a suitable safety valve for free speech, such an understanding was not shared by US citizens concerned by the SOPA and PIPA legislation. Activists pointed to the Department for Homeland Security's Immigration and Customs Enforcement (ICE) unit erroneously shutting down websites for alleged copyright infringements that were not sharing infringing materials, such as a hip-hop blog without allowing the owner the opportunity to appeal that decision prior to the site being taken offline. ${ }^{118}$ With increased public attention being brought to the SOPA/PIPA proposals, online activists began to disseminate information concerning the potential for the legislation to impact upon First Amendment rights, framing their arguments as an explicit conflict between copyright protection and freedom of speech. ${ }^{119}$ The event that significantly raised the profile of antiSOPA/PIPA activists however was the action taken by Wikipedia in January 2012. After discussions between Jimmy Wales, founder of Wikipedia, and Wikipedia collaborators,

\footnotetext{
113 SOPA, s. 104

114 SOPA, s.102

115 SOPA, s.201

116 Stephanie Minnock, 'Should Copyright Laws Be Able to Keep up with Online Piracy' (2014) 12 Colorado Technology Law Journal 523, 533.

117 Issues, 'SOPA/PIPA: Internet Blacklist Legislation' (Electronic Frontier Foundation, 2012)

<https://www.eff.org/issues/coica-internet-censorship-and-copyright-bill> accessed 19 November 2016.

118 MacKinnon (n 108) 102-103.

119 See Annemarie Bridy, 'Copyright Policymaking as Procedural Democratic Process: A Discourse-Theoretic Perspective on ACTA, SOPA, and PIPA' (2012) 30 Cardozo Arts \& Entertainment Law Journal 153; Sandra Schmitz, 'The US SOPA and PIPA - a European Perspective' (2013) 27 International Review of Law, Computers \& Technology 213; and Yoder (n 112).
} 
Wales made the decision to 'black out' Wikipedia on 18 January as a form of protest against the IP Bills. Making the website inaccessible, except for a message stating that the proposed legislation could 'fatally damage the free and open Internet', Wales provided information regarding SOPA, and how concerned US citizens could contact their political representatives regarding SOPA/PIPA, on a page accessed more than 162 million times. ${ }^{120}$ On this basis, more than 8 million people looked up their representatives' contact information using a Wikipedia provided tool.121 This action was mirrored by other leading websites and online communities in a form of 'day of action', with other sites such as Reddit also becoming inaccessible, ${ }^{122}$ and sites like Google and Flickr featuring protests against SOPA/PIPA. ${ }^{123}$ As a result of this coordinated online and offline action, in which the Internet was used to spread information regarding the potential First Amendment concerns of the SOPA/PIPA legislation, and offline contacting of representatives in order to protest against the adoption of the legislation, plans for the legislation were ultimately shelved. The media attention, with newspapers such as the New York Times focusing upon the protests and the concerns of activists, ${ }^{124}$ and the specific framing of SOPA/PIPA as presenting serious First Amendment threats facilitated collaborative and engaged political action that made the position of Congress untenable. ${ }^{125}$ While not necessarily resolving the apparent conflict between copyright and the First Amendment, what the debate over SOPA/PIPA demonstrates is that the judicial perception of there being 'no conflict' is not one shared by citizens.

In the EU, citizen mobilisation centred on the Anti-Counterfeiting Trade Agreement (ACTA). ACTA was a plurilateral trade agreement negotiated outside of the traditional framework of the World Trade Organisation and World Intellectual Property Organisation, which amongst other provisions such as allowing for the seizure and destruction of pharmaceuticals in

\footnotetext{
120 Piotr Konieczny, 'The Day Wikipedia Stood Still: Wikipedia's Editors' Participation in the 2012 Anti-SOPA Protests as a Case Study of Online Organization Empowering International and National Political Opportunity Structures' (2014) 62 Current Sociology 994, 996.

121 ibid 996-997.

122 Richard Mills and Adam Fish, 'A Computational Study of How and Why Reddit.com Was an Effective Platform in the Campaign Against SOPA' in Gabriele Meiselwitz (ed), Social Computing and Social Media (Springer International Publishing 2015) <http://link.springer.com/chapter/10.1007/978-3-319-203676_23> accessed 19 November 2016.

123 Bridy (n 120).

124 Jonathan Weisman, 'In Piracy Bill Fight, New Economy Rises Against Old' The New York Times (18 January 2012) <http://www.nytimes.com/2012/01/19/technology/web-protests-piracy-bill-and-2-key-senatorschange-course.html> accessed 19 November 2016.

125 Peter Jay Smith, 'Speaking for Freedom, Normalizing the Net?' (2013) 10 Journal of Information Technology \& Politics 423.
} 
transit that were believed to infringe upon patents, ${ }^{126}$ also included provisions on the protection of copyright on the Internet. Negotiated between the US, Canada, Australia, the EU, Japan, Mexico, Morocco, New Zealand, the Republic of Korea, Singapore, Switzerland and the US,127 leaks of drafts of the Agreement in 2008, then confirmed by the release of deliberative drafts by the European Commission in 2010 indicated Article 2.14 provided for the imposition of criminal sanctions 'at least in cases of willful trademark counterfeiting or copyright or related rights piracy on a commercial scale', which was intended to include wilful copyright and related rights infringements 'that have no direct or indirect motivation of financial gain'. Article 2.18(1) specifically stated that these sanctions should be applied to cases of wilful infringement that take place by means of the internet/in the digital environment. ${ }^{128}$ In the final text, ACTA Article 27(1), stated that each Party to the Agreement would 'promote cooperative efforts with the business community to effectively address [...] copyright or related rights infringement [...] while preserving fundamental principles such as freedom of expression, fair process, and privacy.' Unlike the legislation proposed in the US, this international agreement did make specific reference to fundamental rights due to the involvement of the EU in negotiations. Indeed, academic opinion was that while there were legitimate concerns regarding the lack of transparency in the ACTA negotiating process, the Agreement itself did not propose any significant changes to the existing EU regime, nor present threats to fundamental rights beyond those that have already been discussed in the context of the Promusicae and Scarlet cases. ${ }^{129}$

Nevertheless, as with concerns over SOPA/PIPA, although legal opinion may have been that there was not necessarily anything in ACTA to upset the existing balance between the protection of copyright and other fundamental rights, this understanding was not shared by online activists. Drawing considerably upon the resistance to SOPA/PIPA in the US, Polish citizens began mobilising activists through Facebook, culminating in a number of anti-ACTA protests taking place in early 2012. Facebook pages such as 'Nie dla ACTA' were set up, which according to a post made on the page on 21 January 2012, had over 10,000 views

\footnotetext{
126 Of particular concern to countries such as India and Brazil, as discussed in Benjamin Farrand and Helena Carrapico, 'Copyright Law as a Matter of (Inter)national Security? - The Attempt to Securitise Commercial Infringement and Its Spillover onto Individual Liability' (2012) 57 Crime, Law and Social Change 373.

127 ibid 392.

128 Farrand (n 107) 181.

129 See for example Farrand (n 107); C Geiger, 'Weakening Multilateralism in Intellectual Property Lawmaking: A European Perspective on ACTA' (2012) 3(2) The WIPO Journal 166; cf Emma Leith, 'ACTA: The AntiCounterfeiting Crack-Down' (2011) 22(3) Entertainment Law Review 81.
} 
within the first 24 hours of being active. By 22 January 2012, this number had reached 100,000 views. ${ }^{130}$ On the 26 January, thousands of Polish protestors marched through the streets of cities such as Warsaw, Krakow and Wroclaw, drawing international press attention. ${ }^{131}$ These protestors framed ACTA not as being an instrument of copyright protection, but as a significant threat to the privacy rights and freedom of expression of EU citizens. As with the attention-raising activities of Wikipedia against SOPA/PIPA, online organisations such as LQDN and Digitale Linke began work facilitating information dissemination regarding ACTA and the perceived threat to 'Internet freedoms'. As a result, a coordinated protest took place in February 2012, including tens of thousands of protestors in Germany, as well as thousands in Bulgaria, France and other EU Member States. ${ }^{132}$ LQDN in particular provided information on how activists could contact Members of the European Parliament (MEP) to voice their concern, including contact details and scripts that could be used by those calling their MEP.133 Through this combination of online activism, increased media attention, and subsequent offline engagement with the political process, the position of the European Parliament on ACTA changed significantly; from being fully in support of it, and urging the Commission to take the action necessary to speedily conclude the Agreement, ${ }^{134}$ the European Parliament instead became concerned regarding the implications of ACTA for the Internet, and fundamental freedoms. The European Parliament, once again affirming the balancing approach of the EU, recommended rejection of ACTA, stating that 'it is crucial to strike the appropriate balance between enforcement of IPRs and fundamental rights such as freedom of expression, the right to privacy and protection of personal data'. ${ }^{135}$ ACTA, it concluded, did not strike such a balance, and as such, had negative implications for rights to freedom expression and privacy. ${ }^{136}$ In June 2012, following

\footnotetext{
130 Farrand (n 107) 184.

131 ibid.

132 Charles Arthur, 'Acta Criticised after Thousands Protest in Europe' (The Guardian, 13 February 2012) <http://www.theguardian.com/technology/2012/feb/13/acta-protests-europe> accessed 19 August 2013. 133 La Quadrature du Net, 'How to Act against ACTA' (La Quadrature du Net Wiki, 2012) <https://www.laquadrature.net/wiki/How_to_act_against_ACTA\#Contact_your_Elected_Representatives> accessed 20 August 2013; La Quadrature du Net, 'Tools' (La Quadrature du Net, 2012) <http://www.laquadrature.net/en/tools> accessed 20 August 2013.

134 European Parliament, 'Motion for a Resolution to Wind up the Debate on the Statement by the Commission pursuant to Rule 110(2) of the Rules of Procedure on ACTA' (European Parliament 2010).

135 Committee on Civil Liberties, Justice and Home Affairs, 'Draft Opinion of the Committee on Civil Liberties, Justice and Home Affairs for the Committee on International Trade on the Compatibility of the AntiCounterfeiting Trade Agreement with the Rights Enshrined in the Charter of Fundamental Rights of the European Union' (European Parliament 2012) 2011/0167(NLE) para 3.

136 ibid 14.
} 
unprecedented citizen engagement with the European Parliament, the ratification of ACTA by the EU was rejected by 478 votes to 39.137

However, it must be stated that citizen participation in the challenging of intellectual property agreements perceived by members of the public as conflicting with other human rights, such as access to information and privacy, is largely dependent upon their awareness of the existence of such agreements, and being framed in language that allows for mobilisation against these legal reforms. ${ }^{138}$ Both the ill-fated Trans-Pacific Partnership and Transatlantic Trade and Investment Partnership agreements appear to be dead with little chance of resuscitation. Both agreements had provisions appearing to mandate copyright enforcement provisions that would impact fundamental rights in similar ways to SOPA/PIPA and ACTA, yet citizen mobilisation against these agreements was not nearly as visible as that against SOPA/PIPA in the US, and ACTA in the EU. Indeed, it was the election of current US President Trump that led to the negotiation of these agreements being suspended, rather than citizen activism, and based on an ostensibly anti-free trade agenda rather than a concern over fundamental rights. Where changes to laws are more complex, and less visible, public engagement with law reforms are significantly reduced, meaning that the balance may be tipped further in the favour of copyright protection, as opposed to other competing human rights interests. What follows these failed initiatives, whether in the EU, US, or internationally, remains to be seen.

\section{CONCLUDING THOUGHTS}

Whereas at the global level, copyright protection is afforded universal human right protection, the level of acceptance of this proposition in different legal regimes varies. The EU has been unequivocal in its affirmation that it affords copyright protection fundamental rights status. It has reiterated this both in binding legislation, as well as in the jurisprudence of its highest court. Yet, it recognises that even as a fundamental right, copyright protection requires balancing against interests represented in other fundamental rights, such as privacy or freedom of expression - copyright is not supreme as a form of right, and the extent of its protections limited in order to ensure effective protection of other competing

\footnotetext{
137 Farrand (n 107) 188.

138 ibid 192-194.
} 
interests. In the US, however, the courts have not reached the same conclusions. The legal position is that copyright facilitates rather than hinders speech, and therefore is not subject to First Amendment analysis. Any potential restrictions of speech can be managed internally, through the fair use doctrine. However, as has been demonstrated, the automation of notice and takedown procedures, as well as the ability to use copyright to suppress information in such a way that fair use cannot be relied upon, brings the US courts' jurisprudence into question. It is a position that Internet activists may not necessarily agree with - it is interesting to note that the unity between the US and EU systems came in the form of citizen protests decrying the expansion of IP rights on the Internet, with both groups mobilising through coordinated online and offline action to combat these perceived threats. For Internet users, expansive copyright protections pose significant threats to privacy, as well as freedom of expression, and they are willing to engage in lobbying in order to prevent that threat. It is difficult, then, to say that between copyright and other human rights, there is no conflict. 